\title{
A STUDY OF GLOBAL RECESSION RECOVERY STRATEGIES IN HIGHLY RANKED GDP EU COUNTRIES
}

\author{
Mythili Kolluru' ${ }^{1}$, Denis Hyams-Ssekasi ${ }^{2}$, K.V.Ch.Madhu Sudhana Rao ${ }^{3}$
}

date of paper receipt:

24.03.2021.

Review Article date of sending to review:

26.03.2021.

doi: 10.2478/eoik-2021-0011 date of review receipt:

10.04.2021.

UDK 330.101.54:331.526.2(4-672EU)

${ }^{1}$ Professional Studies and Undergraduate Dept., College of Banking and Financial Studies; Muscat, Oman, e-mail: mythili@cbfs.edu.om

${ }^{2}$ Institute of Management, University of Bolton, Deane Road, Bolton, BL3 5AB U.K. Email: dh4@bolton.uk,

${ }^{3}$ Cerner Healthcare Pvt Ltd, Bangalore, Karnataka, India. Email: madhukondaveti@gmail.com

\section{ABSTRACT}

The Global financial crisis of 2008-2009 severely impacted the developed economies of the world. It occurred at a time when most countries had started gaining economic growth, stability, and vibrance. Each country experienced a jolt to its economy, causing financial fragility, shocks, tragedy, and struggle. Attempts have been made to understand the root causes, economic instability, and the lessons learned from the great recession. Given the current situation of the COVID-19 pandemic, this research paper seeks to examine the global recession, its effect on the economy and finances. Our research is based on the qualitative analysis of comparing the impact of the global financial crisis and strategic recovery recession plans of the top five GDP countries in the European Unionparticularly Germany, the UK, France, Spain, and Italy to draw some similarities between a recession and COVID-19 pandemic in terms of the economy. The findings indicate that the great recession had a devastating impact on the entire economy, and the world can learn valuable lessons. It notes that out of the selected five EU countries, Germany was the first to recover and bounce back by 2011, but Italy and Spain were severely hit and took longer to recover only partially. The recession recovery strategies demonstrate some similarities in economic and employment measures and differences concerning tax reforms and financial support packages initiated by all five countries. There needs to be a mechanism in which each country must prepare for untimely recessions. Thus, a developmental model has been created to enable countries to be more prepared when faced with recessions in the future years.

\section{Keywords:}

Recession; Strategy; Pandemic; Europe; Economy; Unemployment; Tax reform; Global Financial Crisis; Macroeconomics

JEL Classification: J11, J21, O11, O23, O48, P11, R11, Y11 


\section{INTRODUCTION}

The global economic landscape is marked by rising energy prices, increasing unemployment, the risk to human health, digital divides, cyberattacks, climate change, growing inequalities, geopolitical fragmentation, and COVID-19 Pandemic. Amidst these dire conditions, global leaders are challenged to ensure sustainable growth and development. Policymakers, heads of states, and researchers have since a decade discussing "Global recession," reflecting the various recessions faced globally over the last seven decades. The severity of the 2008-09 global financial crisis bought the world economy to a halt. The global financial crisis started in mid-2007 but spread to the entire world by September 2008. The collapse of Lehman Brothers, the complexity of the mortgage-backed securities, and the unawareness of the liabilities' extent ultimately resulted in a rapid deterioration of the US housing sector. Consequently, liquidity quickly dried up, almost bringing the global financial system to choke. The global recession had severe economic and financial disruptions in many countries worldwide. Advanced economies experienced the brunt of the recession. The situation was more intense than earlier crises such as the Great Depression of the 1930s and the South East Asian Crisis of 1997. In 2010-11, attention shifted with signs of recovery and hope, but it was soon shattered with the fear of another recession with the euro debt crisis. With time, the Euro region pressures began to stabilize in late 2013, but in 2015-16, China's financial market turbulence led to a fear of an upsurge of the global recession. Since the middle of 2018, world leaders have been concerned with the resurgence of another recession.

The world economy experienced a synchronized slowdown because of the extraordinary weakness in trade and amid raised trade tensions and policy uncertainties. In December 2019, a new highly infectious virus, the Coronavirus, in Wuhan, China, started to surface. Since then, it has spread worldwide and has reached an ongoing pandemic. The unexpected Covid-19 Pandemic is unparalleled in its impact on the global economy. It is spreading rapidly and has infected millions, and brings economic activity to a near-standstill situation. Both emerging and developed economies are experiencing economic downturns. These downturns are so deep and intense that they will reverse years of progress made towards developmental goals. The recession triggered by pandemics is expected to leave its mark on the global economic landscape by colossal loss of human life, lowered investment, depletion of human capital development through unprecedented unemployment, and disruptions of education systems and fragmentation of global supply chains, and distortion of international trade.

The novel Coronavirus causes the present crisis, and 2007-2009 was a Global Financial crisis (GFC). However, there are structural variations in terms of the origin of the recession; the critical similarity between the 2007 crisis originated in the USA and China's Coronavirus in 2019 is uncertainty and global spread. Both have resulted in economy-wide stress, contractions to economic growth, economic activity, and employment. The subprime crisis resulted in the freezing of international financial relationships and a sharp increase in tension, including economic policies to tackle this unprecedented situation. The COVID-19 problem also freezes a large chunk of merchant activities in half of the world. The initial drop in the stock exchanges of significant countries is similar between both the crises. And both global recessions have been successively qualified as the largest since the Great Depression. The unemployment rate reached a high of $10 \%$ through the Great Financial Crisis, and now, during the Pandemic, it stands at 14.7\%. As also emerging market economies, advanced economies observed regulation of inflation influences due to rapidly slowing economic activity. Despite the similarities and dissimilarities, each recession offers lessons to better prepare the world for the next downturn. The Global Financial crisis also horrendously impacted the world economy, and the impact was felt across all quarters of the world. The Pandemic is very similar, with a much more profound effect in terms of magnitude and depth. Another point to be 
noted is that the Pandemic is still an ongoing happening. All in all, the COVID-19 is expected to be a deeper recession and will not leave any country unscathed. The Pandemic has claimed thousands of lives and impacted all industry sectors and caused historical loss to specific industries like the airline industry, oil market, and tourism sector.

Against this background, this paper examines the impacts of the global financial crisis and the ensuing recovery strategies adopted by five leading European Union countries. Specifically, it addressed two questions. First, what are the 2008-2009 global recession recovery strategies? Second, how do the global recession recovery strategies learning show the generic path in future crises? The paper builds on exhaustive and extensive literature research which spans the global recessions, COVID-19, and the impact of the recession on Germany, France, Italy, Spain, and the UK to examine the financial crisis and the monetary and fiscal policy reforms in response across five EU countries. (Wolf, 2010), the global financial crisis had a profound impact across many developed economies of the world. All five countries: Germany, France, the UK, Spain, and Italy, experienced a decline in GDP per capita. All of them experienced economic contractions that began from 2008 onwards. The noteworthy point is that only Germany's deficit was hardly affected among the five countries. There were different magnitudes of deterioration in these five countries' underlying public finance positions. The recession bought about an increase in unemployment and a sharp increase in budget deficits. The monetary and fiscal response also differed to some extent. Still, it typically consisted of two parts: Fiscal stimulus, which aimed at mitigating the length and depth of the recession, and fiscal consolidation, which steered at reviving the financial sustainability of the public finance position. The critical analysis of vast data and statistics reveals that Germany's recession strategies, the UK, France, Spain, and Italy, have a standard underlying procedure with country-specific tactics. Based on the shared basic commonalities, we have synthesized a developmental model that countries can adopt by altering the tactics according to country-specific circumstances. The developmental model is categorized into four dimensions: Tax Dimension, Employment Dimension, Economic Dimension, and Small and medium enterprise Dimension. This study aims to analyze 5 top EU countries' recovery strategies in response to the Great Recession and offer a recession recovery model that is simple and a broad framework that provides scope for countries to apply it according to their economic and socio-cultural landscape.

\section{LITERATURE REVIEW}

\subsection{THEORETICAL PERSPECTIVES}

The global recession is not a new concept but extended economic devastation that occurred worldwide. It is generally argued that when there is an economic decline over an extended period, globally, it is known as the global recession Alshubiri et al., (2019) and Rampell (2009), while Reinhart \& Rogoff, (2009) view it as the "Second Great Contraction." The world has experienced varied recessions over the years. Undoubtedly, these recessions have been characterized by a contraction in annual real per-capita worldwide GDP and broad-based weakness in other key indicators of global economic activity in each of these recessions. These recessions between 20082013 are referred to as the great global recession due to their breadth, economic severity, and financial disruptions Kose et al., (2020). Given this Great recession, the International Monetary Fund IMF (2009) describes it as a global slowdown epitomized by a decrease in per capita world gross domestic product (GDP), braced by macroeconomic indicators like capital flow, trade, unemployment, and a drop in GDP for at least two consecutive quarters. IMF estimates that global recessions are cyclic and occur every eight to ten years. 


\subsection{CAUSES OF RECESSION}

The global recession, which is sometimes known as the 2008 Recession, began in the United States and spread to other developed and emerging economies. Bulbarelli (2016) states that the housing market, which seemed booming, resulted in a crisis, leading to a recession towards the end of 2007. Verick \& Islam (2010) explain that in 2009 almost all the developed countries and half of the emerging and developing economies went into crisis. The crisis had an unusual impact due to the interrelatedness of the financial markets and robust international trade. According to Székeky \& van den Noord (2009) some commentators point out that the root which led to the global financial crisis was caused by mortgage defaults, the American housing bubble bursting, relaxed loans, and deregulation in the financial industry caused a global credit crunch that started after 2007/08. It is argued that the worldwide credit crunch continued for an extended period leading to low/negative growth, raised unemployment, business \& consumer confidence fell, companies were not able to borrow the funds required for investments. This great recession highlighted the challenges and discrepancies in the banking system. The world witnessed a decline in economic indicators like aggregate and average per capita global output. Developed and emerging economies experienced a sharp contraction in cross-border trade because of increased linkages developed due to globalization. Based on the country's degree of business and financial openness, the capital inflows fluctuated, the capital flows also reduced. The crisis shook up the international monetary system and created imbalances in economic, housing, and commodity markets. Kahle \& Stulz (2013) argue that the financial crisis of 2007-08 created an unexpected event that disrupted the economy, decomposed supply shock, and made it almost impossible to raise any additional equity. There were issues of economic factors that resulted in lower demand for consumer goods and services. Campello, Graham, \& Harvey (2010) find that raising additional funding was viewed as expensive and problematic due to the persistent drop in demand and cash flows. The consequence resulted in no other demand for financing which led to a fall in debt, stock decrease, and cash holdings due to investment interruptions. Graham, Leary, \& Roberts (2014) account that investment opportunities are scarce, especially during economic uncertainty (downturns), weakening the need for external capital, calumniating in reducing businesses' leverage ratios. In their study Kahle \& Stulz (2013) report that firms rely heavily on public debt markets during a time of financial crisis.

\subsection{RECESSION AND EUROPE}

The global recession had a devastating impact on Western Europe's financial systems, and the damage to the economy was imminent. According to the European Commission (2009), Western Europe was severely hit by the 2008 global financial crisis. Rinne \& Zimmermann (2012) affirm that the crisis resulted in a high rise in unemployment, deterioration of consumption and export, inflation and deflation, house market bursts, inability to obtain credit, sharp fall of consumer confidence, and unwillingness to spend, creating a demand and supply shock. It is noted that consumers and businesses faced difficulties with obtaining credit due to the financial crisis. Failure to receive recognition in countries such as UK and Spain contributed volatile downward trend seen in housing prices. The financial crisis's negative impact necessitated strict measures and responses to revive the European policies' long-term economic growth (Costello et al., 2009). According to the work of Calò (2019) most European nations depended on the government's interventions to deal with the economic and financial crisis of 2008.

The findings of Chima \& Langley (2012); OECD (2009) state that because of the credit crunch, the banks reached out to the UK government for a bailout that led to a bank rescue package. Müller (2013) claims that besides, central banks cut down the interest rates to record low, i.e., $5 \%$ to $0.5 \%$. Germany's government responded quickly to the crisis to boost the economy. It improved the 
country's labour market's functioning by reducing the working hours, short term workers, regulated the market and financial markets, offered a stimulus package, and launched a program like the USA, "Cash for clunkers". Khatiwada (2009) explains that with the failure of many banks and the collapse of France's financial market, the government announced the bank rescue plan to restore customer confidence, which had plummeted to its lowest during the global financial crisis. Similarly, the Italian government adopted the same approach by supporting the bank and large organizations and cutting public spending. Spain sustained its economic systems by purchasing financial assets for lending banks, lowered the income tax, and eliminated capital gains tax. Such interventions proved vital to the recovery of the economy, especially in highly ranked GDP European countries. Verick and Islam (2010) conclude that to overcome the great recession, "governments in both advanced and developing countries react aggressively by injecting massive amounts of credit into financial markets and nationalizing banks, slashing interest rates, increasing discretionary spending through fiscal packages." The works of Ivashina \& Scharfstein (2020); and Brunnermeier (2008) all claim that the government's quick intervention concerning the global crisis did not stop the job losses, unemployment, credit crunch, nor the collapse of the trade flows still, it can minimize the severity of the impact of the recession.

In relation to the current situation, there are parallels between COVID-19 health crisis and the Great recession- financial crisis. The evident challenges arising from both dilemmas are the crippling economy, the economic frustration, unemployment, financial shocks and disruptions. The severity of the damage caused are varied and these depend on each region's economy. It is noted that the global financial crisis dislocated the banking systems and banks had to be bailed out. Nevertheless, the COVID -19 has triggered what was experienced in 2008-2009 such as financial shocks though on a different scale. Kose et al., (2013) state that "The pandemic has brought an abrupt end to financial market tranquility and is now testing the resilience of the economies, institutions, and policies of emerging economies. They are facing an unfolding global recession in a much more vulnerable position than when the 2009 crisis hit". According to IMF (2020) measures have been put in place to protect both individuals and firms from the devastating economic impact caused by the pandemic and to prevent the precarious health crisis from tuning into a financial turmoil. The exhaustive exploration of the literature reveals a rich body of existing knowledge on recessions experienced by the world. However, there is a scope of inquiry which this research attempts to plug. The study presents an in-depth analysis of five leading global economies' impact and recovery strategies considering the 2008-2009 Great Recession. The research further synthesizes a generic developmental model that could be a tool for policymakers and government authorities in times of crisis.

\section{METHODOLOGY}

This study is a qualitative analysis based on a systematic review of literature pertaining to the global financial crisis also commonly known as the Great Recession. For all 28 EU countries GDP analysis was done by taking GDP data from 2000-2019. Using these 20 years GDP data, average was calculated for UK \& EU countries. Based on the average GDP data, ranking was done and the top 5 countries were selected with highest average for further investigation. 
Table 1. Average GDP numbers for the top EU countries

\begin{tabular}{ll} 
Country & $\begin{array}{l}\text { Avg. GDP (In USD } \\
\text { Trillion) }\end{array}$ \\
\hline Germany & 3.21 \\
\hline UK & 2.55 \\
\hline France & 2.39 \\
\hline Italy & 1.91 \\
\hline Spain & 1.22 \\
& Source: World bank
\end{tabular}

Prices do not stay the same. There are changes in the price level (inflation and deflation). Gross Domestic Product (GDP) measures variations in output. The nominal GDP increases with inflation and decreases with deflation. As we want to measure short-run economic growth in measuring performance, real GDP takes out the effects of price change and isolates changes in output. Here, in this paper, we analyse the long run from 2000 to 2019, and therefore we considered taking nominal GDP. Moreover, if we notice for the five countries during our study period, the change in the price was minuscule. The base years for a different country in our study are different, and that would change our result, which is also one reason for taking nominal GDP. However, real GDP is the better indicator of the economy's potential to produce goods and services and take out inflation; Nominal Gross Domestic Product (Nominal GDP) is the total market value of all goods and services produced in a country's economy over a given period. We use nominal GDP to compare economic output in different years. Interestingly, these top 5 countries average GDP across last 19 years is above 1 Trillion, that demonstrates the role of these countries in EU region. These top 5 countries, economic, financial positions, unique strengths were analyzed using the secondary data. During the recession period and after the recession these countries demonstrated their economic growth \& development despite the financial turbulence over the years. Reasons for the economic crisis caused by the Great Recession were considered for the analysis. Variety of the reasons for the Great Recession were identified. During the crisis period, these countries have followed variety of the strategies to recover from the recession were critically analyzed. To arrive at common conditions for recession recovery strategies of the top 5 GDP countries, we compared the individual country on the dimensions of economic measures, employment reforms \& policies, financial support \& stimulus, and tax reforms. Importance of these recovery strategies were measured using recovery trend analysis. Time taken by each country to recover from the crisis was measured using the recovery trend analysis. Additionally, statistical analysis of information synthesis, descriptive analysis was conducted to arrive at a developmental model as a strategic approach for the future crisis. 


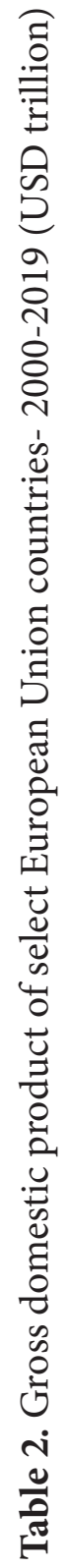

\begin{tabular}{|c|c|c|c|c|c|}
\hline 亏े & $\begin{array}{l}\infty \\
\infty \\
\sim\end{array}$ & $\underset{\substack{\infty \\
i}}{ }$ & 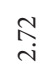 & $\underset{i}{\stackrel{O}{~}}$ & $\stackrel{\text { mे }}{\text { - }}$ \\
\hline$\stackrel{\infty}{\stackrel{\sim}{*}}$ & 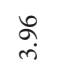 & 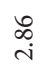 & 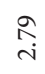 & $\underset{\dot{i}}{\hat{i}}$ & $\stackrel{f}{\rightarrow}$ \\
\hline$\widehat{\tilde{N}}$ & $\begin{array}{l}\mathscr{\infty} \\
\dot{r}\end{array}$ & $\underset{\mathrm{i}}{\hat{i}}$ & 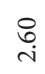 & $\stackrel{\circ}{\stackrel{2}{2}}$ & $\vec{m}$ \\
\hline ڤั่ & में & $\underset{\mathrm{i}}{\mathrm{i}}$ & f & $\stackrel{\infty}{\stackrel{\infty}{+}}$ & $\stackrel{\overbrace{}}{]}$ \\
\hline$\stackrel{n}{\tilde{N}}$ & 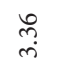 & $\stackrel{\mathscr{S}}{\stackrel{i}{s}}$ & $\underset{i}{\stackrel{H}{i}}$ & $\stackrel{+\infty}{-\infty}$ & 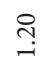 \\
\hline$\underset{\sim}{\mathbb{N}}$ & $\begin{array}{l}\infty \\
\infty \\
\sim\end{array}$ & 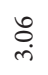 & $\begin{array}{l}\infty \\
\stackrel{\infty}{i} \\
i\end{array}$ & 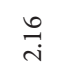 & $\stackrel{\text { m}}{-}$ \\
\hline$\stackrel{m}{\tilde{N}}$ & 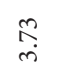 & $\stackrel{\widehat{\hat{i}}}{\text { in }}$ & $\begin{array}{l}\overrightarrow{0} \\
\stackrel{i}{i}\end{array}$ & $\underset{i}{\stackrel{H}{i}}$ & $\stackrel{\leftrightarrow}{\rightarrow}$ \\
\hline$\stackrel{\sim}{\sim}$ & 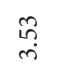 & $\underset{i}{\stackrel{R}{i}}$ & $\begin{array}{l}\infty \\
\stackrel{i}{0}\end{array}$ & $\underset{\dot{i}}{\hat{i}}$ & $\stackrel{\widetilde{\sim}}{-}$ \\
\hline$\overline{\text { N }}$ & $\underset{\sim}{\stackrel{H}{n}}$ & : & $\begin{array}{l}\stackrel{0}{\infty} \\
\stackrel{i}{i}\end{array}$ & तે & $\stackrel{\infty}{\stackrel{+}{-}}$ \\
\hline 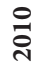 & $\stackrel{\text { P }}{\text { r }}$ & 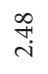 & $\underset{\mathrm{C}}{\stackrel{+}{0}}$ & $\stackrel{m}{i}$ & $\stackrel{f}{\rightarrow}$ \\
\hline ڤ్సે & $\underset{j}{\stackrel{f}{n}}$ & $\underset{i}{\vec{i}}$ & 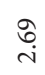 & $\stackrel{\vec{\lambda}}{i}$ & $\stackrel{\text { f }}{\rightarrow}$ \\
\hline ¿্রి & $\stackrel{n}{\infty}$ & $\tilde{i}$ & $\tilde{\widetilde{d}}$ & $\underset{\substack{+i}}{ }$ & $\stackrel{\mathscr{\rho}}{\text {. }}$ \\
\hline 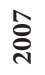 & $\underset{\sim}{\mathscr{f}}$ & 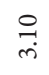 & $\begin{array}{l}\stackrel{\circ}{i} \\
\text { i }\end{array}$ & $\overrightarrow{\widetilde{N}}$ & $\stackrel{f}{+}$ \\
\hline ๕్సి & $\underset{\text { S }}{\text { in }}$ & $\underset{i}{\vec{i}}$ & $\tilde{\widetilde{d}}$ & $\stackrel{\leftrightarrow}{-}$ & 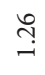 \\
\hline ڤે & $\begin{array}{l}\infty \\
\stackrel{L}{i} \\
i\end{array}$ & $\begin{array}{l}\stackrel{H}{\mathrm{n}} \\
\mathrm{N}\end{array}$ & $\underset{\text { ते }}{\text { in }}$ & 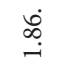 & $\stackrel{2}{\rightleftarrows}$ \\
\hline ث্ণ & 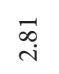 & $\underset{i}{\mathcal{I}}$ & $\underset{\mathrm{i}}{\stackrel{2}{*}}$ & $\stackrel{\infty}{\infty}$ & $\stackrel{\hat{O}}{.}$ \\
\hline ڤ్సి & $\stackrel{\substack{h \\
i}}{ }$ & $\stackrel{\stackrel{\leftrightarrow}{\leftrightarrow}}{i}$ & $\stackrel{+}{\stackrel{\leftrightarrow}{-}}$ & $\stackrel{\hat{n}}{=}$ & $\vec{a}$ \\
\hline ڤ్ & $\stackrel{\hat{i}}{i}$ & $\stackrel{\infty}{\stackrel{\infty}{-}}$ & $\stackrel{g}{\rightarrow}$ & $\stackrel{\widehat{~}}{-}$ & ㅊ. \\
\hline ప్రి & $\stackrel{\leftrightarrows}{-}$ & 节 & $\stackrel{\infty}{\rightarrow}$ & 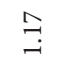 & $\stackrel{\leftrightarrow}{0}$ \\
\hline ఫัసి & $\stackrel{\text { S }}{\rightarrow}$ & مْ: & 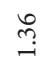 & $\underset{J}{ \pm}$ & : \\
\hline 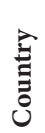 & 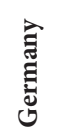 & J & 苛 & 疍 & $\begin{array}{l}\text { के } \\
\text { की }\end{array}$ \\
\hline
\end{tabular}




\section{RESULTS}

\subsection{GERMANY}

\subsubsection{IMPACT OF 2008-2009 RECESSION ON GERMAN ECONOMY}

Germany is firmly an export-oriented country, and its status is mirrored in its economic stability. The 2008-2009 economic downturn impacted Germany in several ways. It is argued that the global recession affected Germany because of three fundamental reasons: firstly, the interdependencies of the financial markets. Secondly, the massive German exports to the USA. Thirdly, the decline in individuals, households, and firm expectations. Due to the financial crisis caused by the recession, German exports declined, especially in the capital goods industry. The GDP began to decline in 2008, and the export-oriented sectors faced an output decline. Rinne (2002) argues that the main factor affecting the German economy was a transitory external demand shock, while Harari (2014) alludes to the world trade flows that led to Germany's deep recession. It is also noted that the global recession had a heterogeneous impact on Germany. The economically federal states like Baden-Württemberg, where many small and medium industries were located, reported the most significant output declines, Rinne (2012). Other cities like Berlin and Schleswig-Holstein, which have fewer international linkages, reported relatively moderate GDP decline. Rinne (2012) alludes the same trend was observed in the annual unemployment rates. Some of the eastern German states did not experience any increase in unemployment rates at all. Unlike the other European countries, the crisis did not translate into an employment decline.

\subsubsection{GERMAN RECESSION RECOVERY STRATEGIES}

The German recovery strategy to the global financial crisis is of interest in how the government performed a vital part in dealing with the crisis. Germany's recession was short-lived as the country started to recover economically in the fourth quarter of 2009, at least in a few sectors. The recession ended in 2011. The circumstances are related to the improved functioning of the country's labor market, the specific nature of the crisis in the German context, and the concrete policy responses in this critical period that supported Germany to face the crisis. The reforms adopted by the German government included the introduction of the labor market reforms, supported by the German economy's recovery. According to Caliendo (2009) a significant response of the labor market was a reduction in the working hours to fight the crisis. Starting in late 2008, a massive expansion of workers receiving government-sponsored subsidies for reduced working hours. Brenke et al., (2011) point out that Short-time work (STW) was a public program that allowed organizations facing economic challenges to reduce the hours worked temporarily while giving their employees income support from the state for hours not worked. The STW program supported the employers as they saved money in training and severance payments when Germany faced a shortage of skilled workers. According to Zapf \& Brehmer (2010) German companies with more than 20 employees utilized working time accounts. When employees worked fewer hours than their employment contract, working time accounts ensured they had balanced the debts later. Bohachova et al., (2011) state that was working time accounts helped company's smooth employment levels and adjust working hours over the business cycle; Brenke et al., (2011) argue that amidst the great recession and financial crisis, the unemployment increased slightly.

Germany's Government introduced regulations on capital and financial markets to speed up the recovery process. The Government also offered stimulus packages of $€ 36$ billion in 2009 and $€ 46$ billion in 2010. The first package included a personal income tax-deductibility of health care contributions, increased child benefit, child tax deduction, and a reduced unemployment insurance contribution. Schäfer \& Zimmermann (2009) write that the second stimulus package's 
central budget items were investments in transport infrastructure, income tax-deductibility of handymen services, and a more attractive depreciation of assets in immovable property. Schäfer \& Zimmermann, (2009) claim the German Government launched a "cash for clunkers" program. Car owners willing to buy a new car in exchange for their at least 9-year-old vehicle would receive a subsidy of $€ 2,500$. According to the research of Blum and Freye (2009) the grant helped stabilize private consumption, and windfall gain was substantial. Furthermore, the Government initiated a budgeted (EUR 115 bn) credit and guarantees program. The program supported small and medium-sized enterprises and larger enterprises.

\subsection{THE UNITED KINGDOM}

\subsubsection{IMPACT OF 2008-2009 RECESSION ON UK ECONOMY}

Before the crisis, UK was experiencing economic growth, low inflation, and interest rates. Nevertheless, the advent of the 2008-2009 global recession hit hard the UK economy resulting in poor economic growth and the experience of depression concerning national income. During the financial crisis, the UK struggled with the Mortgage rates leading to a housing bubble. The banks were severely affected by the global recession. It is argued that the credit crunch and banking crisis resulted in a very sharp drop in real GDP across all major economies. Few banks were short of liquidity resulting in a fall in confidence leading to lower spending and investment. These include the Northern Rock. Bradford \& Bingley, Lloyds, TSB, HBOS, and the Royal Bank of Scotland. Furthermore, due to the deep recession, government tax revenues went down, resulting in budget deficits. Concerning the labor market, the recession resulted in a high employment rate in the UK. It is noted that since the start of the global recession, employment growth has been overwhelmingly concentrated in high-skilled occupations, which saw an increase of 10 percent.

\subsubsection{THE UK RECESSION RECOVERY STRATEGIES}

The UK is perceived as a capitalist country with government interventions during the economic crisis. With the credit crunch, the banks reached out to the UK government for a bailout equivalent to almost 20 percent of GDP. Given the crisis, particularly during the 2 nd half of 2008 and early 2009, the UK Central banks cut down the interest rates to record low, i.e., 5\% in September 2008 to $0.5 \%$ in March 2009. The cut in interest would have meant increased consumption by having borrowings available at a lower price. However, this was not the case. It was to avoid the fall of the economy. On 14 January 2009, the Government further supported banks to boost the economy. Hence, banks were able to lend money to businesses on two fronts. i) Enterprise Finance Guarantee: $75 \%$ government guarantee of bank lending to firms with under $£ 25$ million turnovers (up to $£ 1.3$ billion). ii) Working Capital Guarantee. Various banks are contributing to the fund (£75 million). Due to the deep recession, government tax revenues went down, resulting in budget deficits. This occurred in the countries which heavily relied on stamp duty and taxes. So, to overcome this UK did a moderate degree of fiscal expansion by introducing a temporary cut in VAT and extra spending. The Treasury optimized banks into buying up shares and nationalizing banks that were in jeopardy. Besides, a large sum of money was put into the Financial Services Compensation Scheme to re-assure savers about the safety of their savings. It is noted that money was lent directly to some bankrupt banks to safeguard the customers (banked in high-interest rates) the first $£ 50,000$ of their investment. To avoid any other fiasco, they nationalized some of the unsafe banks. Despite the challenges caused by the financial crisis, Akbar, Rehman, \& Ormrod (2013) contend that the crisis did not significantly impact the long-term financing channels for UK private firms but impaired the financing channels of short-term debt and trade-credit for these firms. 


\subsection{ITALY}

\subsubsection{IMPACT OF 2008-2009 RECESSION ON THE ITALIAN ECONOMY}

Before the global recession, Italy had been in a dire economic state, faring worse in every state. According to Morsy \& Sgherri (2010), Italy's problems were due to unsatisfactory performance, poor productivity, and low-income growth even before the crisis. The decline in output is mainly accounted for by a collapse in productivity. Hence, the 2008-2009 global financial crisis (GFC) impacted Italy's crumbling economy. This is echoed by Quirico (2010) who states that the "global crisis in Italy has impacted on a system that had deteriorated after twenty years of political instability and economic decline." Besides, there was a sharp fall in exports, investment dropped and inventories were cut. Morsy \& Sgherri (2010) argue that despite solid household balance sheets, private consumption also declined significantly, possibly reflecting uncertainty, rising unemployment, and tighter consumer credit. Furthermore, the Lehman Brothers bankruptcy in September 2008 had a severe effect on the Italian economy. It exposed the seriousness of the financial crisis and bought a contraction in the interbank loan market. The lack of liquidity and the soundness of borrowers affected the lending activity of banks. The crisis affected the large banks, and the stock market collapse devaluated their assets. Credit restriction and pessimistic outlook declined customer spending. Similarly, the economic crisis affected public finance. Quirico (2010) argues that the cut in economic activity led to the reduction of taxes, increase in the significant budget deficit, and national public debts. The GFC had a severe impact on the Italian economy, and the real estate, house building, and cars collapsed. The industries reduced their costs, profits margins, and laid-off employees. There was an increase in unemployment, but mostly the young and low-paid workers were affected. The government tax collections reduced, and anti-crisis expenditure increased. In the Italian industry, small businesses make up $95 \%$ of the enterprises and account for $50 \%$ of the employment. Bugamelli et al., (2009) state that the recession has the most significant impact on small enterprises in terms of investments and jobs.

\subsubsection{ITALIAN RECESSION RECOVERY STRATEGIES}

According to Quirico (2010), the Berlusconi government adopted a two-way approach to deal with the global recession that crippled the Italian economy. First, they began supporting the banks and large organizations. Second, they cut public spending. They aimed to curtail the domino effect by supporting banks and helped to retain employees. The Italian administration is characterized by the superimposition of levels of governance, nepotism, and corruption. The complex bureaucratic system and procedures have distorted competition. The government has a reasonable crisis management policy, but they failed to develop an effective strategy to implement the crisis management policy. Italy had a prolonged recovery from the 2008 global financial crisis. The slow recovery indicated a symptom of the permanent decline in GDP following a financial crisis. The Italian government decided to use instruments like job-security agreements and the Cassa Integrazione Guadagni, (CIG) - special public fund used by government to subsidise employees' wages especially those that working at reduced hours It released "social shock absorbers", which considerably reduced the number of dismissals and improved the employment situation. To kick-start growth, the Italian government launched austerity measures that bought the deficit down momentarily. It introduced solidarity tax on incomes above 300,000 Euros and also reduced the tax for low wage workers and increased tax credits. Furthermore, it reduced public spending and this catapulted by cuts to spending on public services. Despite the changes in the economy, Italy took a long time to recover from the financial crisis as compared to other countries of the Euro region. The Italian government debt at $128 \%$ of GDP, ranks as the second biggest debt ratio. 


\subsection{FRANCE}

\subsubsection{IMPACT OF 2008-2009 RECESSION ON THE FRENCH ECONOMY}

According to Schmidt (2009) the French economy is capitalistic and relies heavily on government interventions. Before the 2008-2009 global recession, France's financial system was solid, and banks were considered sufficiently capitalized and intensely consolidated, which Howard (2013) referred to as a "balanced business model. However, the Subprime crisis impacted the commercial and mutual banks, which led to the failure of many banks, the collapse of financial markets, changes in household consumptions, and the deterioration of confidence among various country sectors. The French household consumption patterns changed as house prices fluctuated. Many companies collapsed, leading to a rise in the unemployment rate in the French labour market. The financial crisis equally impacted both the small and the prominent entrepreneurs. The trade crisis had a noticeably sectoral focus; the equipment, intermediate goods, and the automotive industry were the most affected sectors. Araujo \& Martins (2009) conclude that the slump in trade associated with the deterioration of demand and activity worldwide harmed all sectors. More generally, the crisis severely hit firms in industries heavily dependent on external finance, irrelevant to the size or degree of firms' export diversification, confirming the crisis's financial origin. The unemployment rate rose to $9.5 \%$ in 2009 , and around 2.6 million people were affected. The linkages between the banks, financial markets, and companies led to the French economy's collapse. Howard (2013) argues that the French banking system encountered more financial issues, especially during the global recession.

\subsubsection{FRENCH RECESSION RECOVERY STRATEGIES}

In response to the global downturn, French capitalism had to be reconfigured to combat the financial crisis. In 2008, the French government announced the bank rescue plan to restore confidence and liquidity in the French financial system. They also initiated the restructuring of the troubled banks and ensured that they had refined and recapitalized schemes Hardie \& Howarth, (2009); Jabko \& Massoc (2012). France tightened its response to the crisis by reducing the effective corporation tax rate while broadening the tax base. France relied relatively heavily on tax rises (comprising 65 percent and 58 percent of measures, respectively). Reductions in public spending brought about cuts to spending on public services. Furthermore, to reduce small companies' failure, insolvency, and bankruptcy, the French government set up a new reform to launch a company. This form of business simplified the process of starting new ventures. The idea was that anyone could create a micro-enterprise to complete their income and live independently with this type of business. In the wake of the financial crisis, the French government also launched an automobile sector rescue package. The car industry is one of the essential manufacturing industries in France. One of every two cars gets exported, mainly to other EU countries. According to Wilks (2009) the car rescue package has three goals: first, to offer short-term support for demand and jobs in the car industry. Second to develop an industrial policy to ensure the future in a strategic hi-technology industry. Third, to encourage the production of cleaner cars. The government also released 600 million euros for equipment for financial support to subcontractors. The car package did not result in demand for cars. The car sales were hard hit as most of the vehicles are bought on credit, so the credit crunch dried up the demand. 


\subsection{SPAIN}

\subsubsection{IMPACT OF 2008-2009 RECESSION ON SPAIN ECONOMY}

Spain was viewed as Europe's most successful economy before the great recession. During the growth of its economy, Spain performed far better than other countries while other countries struggled. Spain saw uninterrupted growth and greatly benefitted from its continuous expansion of the economy. The government reformed its welfare systems and labour markets, as well as improving flexibility and lowering unemployment. During the great recession, Spain underwent a Financial, Fiscal, and Competitiveness performance so-called triple crisis i.e. Fiscal crisis, Loss of Competitiveness \& Financial crisis. The economic growth became fragile due to low productivity and a decrease in external competitiveness. Aceleanu (2013) argue that economic unbalances such as the current account deficit, persistence inflation, weak productivity growth, declining competitiveness, increased costs of labour, overconsumption, low saving rates drove the country to an economic crisis. Rahman et al., (2017) notes that most productive activities like energy, industry, and financial services contributed only $11 \%$ of GDP growth. By 2009 the GDP had fallen to $3.7 \%$, the spectacular rise in unemployment, the public deficit reached a record $11.4 \%$ of GDP. Consumer confidence was shattered, and all these had an impact on disposable income. With the global financial crisis hitting Europe, Spain encountered a real estate bubble burst, an increase in unemployment, budget deficit, and a deep economic downturn. Jasiński \& Mielcarz, (2013) state that the government responded with an 8 billion euros stimulus. This stimulus, along with a dramatic fall in revenue, led to a large deficit.

\subsubsection{SPAIN RECESSION RECOVERY STRATEGIES}

Spain was affected by the global recession due to the worldwide crisis, not its financial challenges. The initial reaction to such a situation was the sustainability of Spain's economic systems. Thirty billion Euros of state fund was allocated, which aimed at purchasing financial assets of lending banks, gave 6.75 billion Euros for the financial shares in financial entities through the Ordered Bank restructuring and gave 100 billion Euros for the issuance of bonds. The Spanish government put financial measures to create employment opportunities. Thus, allocated 8 billion Euros to towns to conduct job-generating activities; 3 billion Euros for Special State Fund to spur the economy and jobs. And given 20 billion Euros to help and deal with the rise in spending and offset income losses in payments. Furthermore, the government adjusted in the housing sector. Rahman et al., (2017) states that to handle the financial crisis, the government put some measures to support the small and mid-sized companies which were severely affected. Hence, there was an allocation of 5 billion Euros through the Official Credit Institute. Concerted efforts were made to boost the low economic growth. The research of Muñoz, Modroño, Addabbo, (2014) describes how the government provided allowances for business payments to Social Security. Subsequently, there was a tax deduction. It is noted that the income tax was lowered by 400 euros for all taxpayers and eliminated capital gains tax. Furthermore, the Spanish government called for a reform in the banking sector. Rahman et al., (2014) and Carballo-Cruz, (2011) affirm that this led to a creation of a new institution termed as "Fund for Orderly Bank Restructuring (FROB), which played a vital role in facilitating the process of restructuring the banks to strengthen their insolvency. 
Table 3. Percentage change in GDP and unemployment across selected EU countries (2008-2009)

\begin{tabular}{ccc}
\hline Country & \% change in GDP & $\begin{array}{c}\text { \% change in } \\
\text { unemployment }\end{array}$ \\
\hline UK & -5.9 & 2.7 \\
\hline Germany & -6.3 & -0.1 \\
\hline France & -3.1 & 2.4 \\
\hline Spain & -4.3 & 9.7 \\
\hline Italy & -6.5 & 1.8 \\
\hline
\end{tabular}

Source: OECD (2009)

Table 4. Stimulus package for 2008-2009 crisis

\begin{tabular}{ccccc}
\multirow{2}{*}{ Country } & \multicolumn{2}{c}{$\begin{array}{c}\text { Tax cuts and fiscal } \\
\text { expenditure }\end{array}$} & \multicolumn{2}{c}{$\begin{array}{c}\text { Extra credit and similar } \\
\text { measure }\end{array}$} \\
\cline { 2 - 5 } & Euro Billion & \% of GDP & Euro Billion & \% of GDP \\
\hline Germany & 35.8 & 1.4 & 70.3 & 2.7 \\
\hline Spain & 12.3 & 1.1 & 54.3 & 4.9 \\
\hline France & 14.3 & 0.7 & 41.5 & 2.1 \\
\hline Italy & -0.3 & 0.0 & 0.0 & 0.0 \\
\hline UK & 16.5 & 1.0 & 22.1 & 1.4 \\
\hline
\end{tabular}

Source: Authors compilation from national sources

Table 5. Fiscal stimulus package by selected EU countries

\begin{tabular}{|c|c|c|c|c|c|c|c|c|c|c|}
\hline Stimulus & \multicolumn{2}{|c|}{ France } & \multicolumn{2}{|c|}{ Spain } & \multicolumn{2}{|c|}{ Germany } & \multicolumn{2}{|c|}{ Italy } & \multicolumn{2}{|c|}{ UK } \\
\hline (Euro) & Billion & $\%$ & Billion & $\%$ & Billion & $\%$ & Billion & $\%$ & Billion & $\%$ \\
\hline $\begin{array}{l}\text { Total public } \\
\text { investment }\end{array}$ & 8 & 0.4 & 8 & 0.7 & 7.2 & 0.3 & 1.4 & 0.1 & 2.3 & 0.15 \\
\hline $\begin{array}{c}\text { Advance cash } \\
\text { support to } \\
\text { enterprises }\end{array}$ & 13.9 & 0.7 & 7.7 & 0.7 & 15 & 0.6 & 0.2 & 0 & - & - \\
\hline Sectoral aid & 2 & 0.1 & 3 & 0.3 & - & - & - & - & 0.7 & 0.05 \\
\hline $\begin{array}{l}\text { Employment } \\
\text { aid to } \\
\text { householders }\end{array}$ & 2 & 0.1 & 5.9 & 0.5 & 23 & 0.9 & 3.3 & 0.2 & 4.4 & 0.29 \\
\hline Others & - & - & - & - & 4.8 & 0.2 & 1.5 & 0.1 & - & - \\
\hline
\end{tabular}

Table 6. VAT standard and reduced rates by select EU countries in crisis

\begin{tabular}{ccc}
\multirow{2}{*}{ Country } & \multicolumn{2}{c}{ Value added tax (VAT) $\%$} \\
\cline { 2 - 3 } & Standard rate & Reduced rate \\
\hline Germany & 19 & 7 \\
\hline Spain & 16 & 7 \\
\hline France & 19.6 & 5.5 \\
\hline Italy & 20 & 10 \\
\hline UK & 15 & 5 \\
\hline \multicolumn{3}{c}{}
\end{tabular}




\subsection{THE ROAD TO RECOVERY OF SELECT EU COUNTRIES}

Table 7. Gross domestic product of select European Union countries (USD Trillion)

\begin{tabular}{ccccccccc}
\hline \multirow{2}{*}{ Country } & $\begin{array}{l}\text { Pre- } \\
\text { crisis } \\
\text { GDP }\end{array}$ & \multicolumn{2}{c}{$\begin{array}{c}\text { Crisis Period } \\
\text { GDP }\end{array}$} & \multicolumn{5}{c}{ Post crisis Period GDP } \\
\cline { 2 - 10 } & $\mathbf{2 0 0 7}$ & 2008 & 2009 & 2010 & 2011 & 2012 & 2013 & 2014 \\
\hline Germany & $\mathbf{3 . 4 2}$ & 3.73 & 3.40 & 3.40 & $\mathbf{3 . 7 4}$ & 3.53 & 3.73 & 3.88 \\
\hline UK & $\mathbf{3 . 1 0}$ & 2.92 & 2.41 & 2.48 & 2.66 & 2.70 & 2.79 & 3.06 \\
\hline France & $\mathbf{2 . 6 6}$ & 2.92 & 2.69 & 2.64 & 2.86 & 2.68 & $\mathbf{2 . 8 1}$ & 2.85 \\
\hline Italy & $\mathbf{2 . 2 1}$ & 2.40 & 2.19 & 2.13 & 2.29 & 2.09 & 2.14 & 2.16 \\
\hline Spain & $\mathbf{1 . 4 7}$ & 1.63 & 1.49 & 1.42 & 1.48 & 1.32 & 1.35 & 1.37 \\
\hline
\end{tabular}

Source: https://europa.eu/european-union/about-eu/countries_en

Table 8. Recovery Trend details for the top 5 EU Countries (USD Trillion)

\begin{tabular}{|c|c|c|c|c|c|c|}
\hline Country & $\begin{array}{c}\text { GDP } \\
2007\end{array}$ & $\begin{array}{c}\text { Complete } \\
\text { Recovery } \\
\text { GDP }\end{array}$ & $\begin{array}{c}\text { Complete } \\
\text { Recovery } \\
\text { Year }\end{array}$ & $\begin{array}{c}\text { Partial } \\
\text { Recovery } \\
\text { GDP }\end{array}$ & $\begin{array}{c}\text { Partial } \\
\text { recovery } \\
\text { Year }\end{array}$ & $\begin{array}{c}\text { No. of } \\
\text { Years to } \\
\text { recover }\end{array}$ \\
\hline Germany & 3.42 & 3.74 & 2011 & - & - & 2 \\
\hline UK & 3.10 & - & - & 3.06 & 2014 & 6 \\
\hline France & 2.66 & 2.81 & 2013 & 2.86 & 2011 & 5 \\
\hline Italy & 2.21 & - & - & 2.16 & 2014 & 6 \\
\hline Spain & 1.47 & - & - & 1.48 & 2011 & 2 \\
\hline
\end{tabular}

Source: https://data.worldbank.org/indicator/NY.GDP.MKTP.CD

Figure 1. Recovery Trend for the top 5 EU Countries

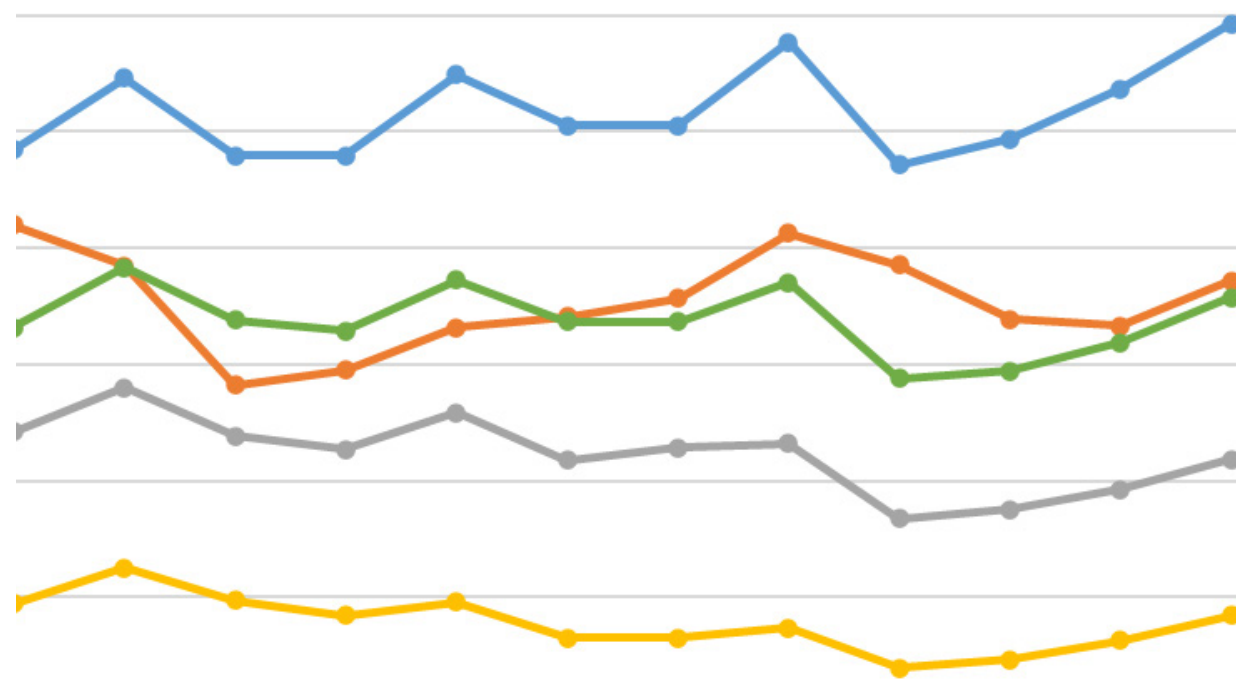




\section{DISCUSSION}

The world has experienced four recessions overall in the last seven decades. Due to each recession, the global annual real per capita has contracted. To bring back the normalcy, the countries has implemented various strategies. A global recovery involves broad-based multiple governmental approaches, which are both financial and economic. The analysis of the big five economies in the European Union region has interesting learnings to offer. The magnitude of the impact differed from country to country, but there was a striking difference in recovery though they adopted similar recovery strategies. All five of the countries in our study experienced a sharp decline in GDP with the advent of the global financial crisis. The magnitude of the impact differed from country to country, but there was a more striking difference in the subsequent recoveries. Based on the information in (Table VII) and (Table VIII) Germany and France have completely recovered from the crisis and were able to scale up the GDP to pre-crisis values. Germany was the first to recover from the crisis in 2 years. France made a partial recovery in 2011 but was not able to sustain the GDP but finally in 2013 the GDP recovered to the pre-crisis levels. France took 5 years to recover. UK made a partial recovery in 2014 with a GDP value of 3.06 which was close to the pre-crisis value of 3.10. It took UK six years to reach this level. Based on (Table II) UK GDP stands at USD 2.83 Trillion in 2019. Spain made a quick partial recovery in two years and reached a GDP of 1.48 which was higher than the pre-crisis GDP value but could not sustain the growth in GDP beyond 2011. After 2011 the GDP began to slide down and it stands at USD 2.39 Trillion in 2019. The analysis shows that only Germany and France have completely recovered. UK took a period 6 years to recover from the crisis and Italy and Spain only achieve partial recovery for brief periods of time. After a critical analysis of the five countries' impact and recovery strategies, the overall strategy has been grouped into four dimensions: the basis for the developmental plan.

\subsection{TAX DIMENSION}

All five countries in the study introduced tax reforms, respectively. Germany introduced tax deductions for specific sectors like health care contributions, increased child benefits. All five countries reduced the Value Added Tax (VAT). UK also increased tax for certain specific goods like tobacco and alcohol. Spain lowered taxes for all taxpayers and eliminated capital gain tax. Italy lowered taxes for reduced wage earners and expanded tax credits. All countries except Germany increased tax rates. France increased tax-rate from $19.6 \%$ to $20 \%$. Italy tax rate rose from $20 \%$ to $22 \%$. Spain increased the introductory rate from $16 \%$ to $21 \%$, and the UK increased its primary rate from $17.5 \%$ to $20 \%$. These countries made changes to their income tax systems to focus on revenueraising-especially on higher-income individuals. Two countries made changes to the marginal tax rates; France raised the marginal tax rate from $40 \%$ to $45 \%$, Spain also increased the marginal rate from $43 \%$ to $52 \%$ whilst Italy introduced the solidarity tax and the UK introduced a new 50\% top rate of income tax. Although the tax's size has varied, we can observe some similarities in Germany, France, Spain, Italy, and the UK.

\subsection{EMPLOYMENT DIMENSION}

All five top GDP countries introduced country-specific flagship programs to subsidize employee wages-governments of Spain, Germany, the UK, France, and Italy launched job security agreements. UK launched a welfare scheme to generate alternate employment income for citizens. All countries devised their own country-specific approach towards shortened hours scheme for citizens across all sectors. All five countries experienced different changes in overall employment prospects. The primary measure that cushioned the impact of the crisis on unemployment rates was reduced working hours which resulted in high underemployment. From (Table III) we can 
see France has a fall of 3\% in GDP and a similar rise in unemployment. Many countries deliberate policy to encourage short-term working avoided employee terminations. Italy had a similar subsidy scheme. The UK has experienced less employment loss. Spain had strong labour protection with a larger share of temporary jobs and was thus more vulnerable in the downturn.

\subsection{ECONOMIC DIMENSION}

Concrete policy response and flexibility supported most of the five countries to face the recession. Besides capital and financial market reforms Germany, Spain, France offered stimulus package dimension. France, UK, Spain, and Italy announced bank rescue packages to restore confidence and liquidity in their respective financial system. France began restructuring troubled banks. The UK devised three approaches to rescue banks. They invested heavily in rescue packages to bail out banks from bankruptcy. Germany also launched stimulus packages, but they were focused on saving banks. Spain, Italy, and the UK went for fiscal tightening to move in a sustainable path. Only Germany did not make any net budgetary adjustments. Spain did fiscal tightening to the tune of $9 \%$ of national income. France, Italy, and the UK did to the tune of 5 to $6 \%$ of national income. France and Italy relied heavily on tax rise measures. Spain and the UK became the lower-tax economies, and France and Italy became the high-tax economies, whereas Germany only did a modest net tightening. According to the (Table V), the stimulus packages varied substantially by country. For evaluation, the fiscal stimuli are categorized into tax cuts and government-sponsored extra credit to producers and consumers. The highest stimulus was by Germany. Italy, France, and the UK engaged in marginal fiscal stimulus. Spain was more active in extra credit.

\subsection{SMALL AND MEDIUM ENTERPRISE DIMENSION}

All five countries introduced country-specific sectoral reforms. Germany introduced the cash for clunkers programs. France also supported the automobile sector, essential manufacturing industries, and transport infrastructural sector. The Italian government launched plans for bank rescue but did not find much information on sectoral reform found across the literature. Spain also released heavy funds to support small and medium-sized companies and specific reforms for the automobile sector.

The recession strategies of Germany, the UK, France, Spain, and Italy have a common fundamental approach with country-specific tactics. Based on the shared basic commonalities, we have developed a developmental model that countries can adopt by tweaking the tactics according to countryspecific economic and social-cultural perspectives. In UK, banks lend money to business based on guarantees. The developmental model is presented in the figure below and is categorized into four dimensions: Tax Dimension, Employment Dimension, Economic Dimension, and Small and medium enterprise Dimension. These four dimensions summarize the common recovery strategies adopted by the top five European Union countries. The developmental model is a synthesis of the recovery strategies adopted by Germany, UK, France, Spain, and Italy. The model provides options which countries can explore and adopt based on their respective country specific circumstances. 
Figure 2. Recession Recovery Developmental Plan

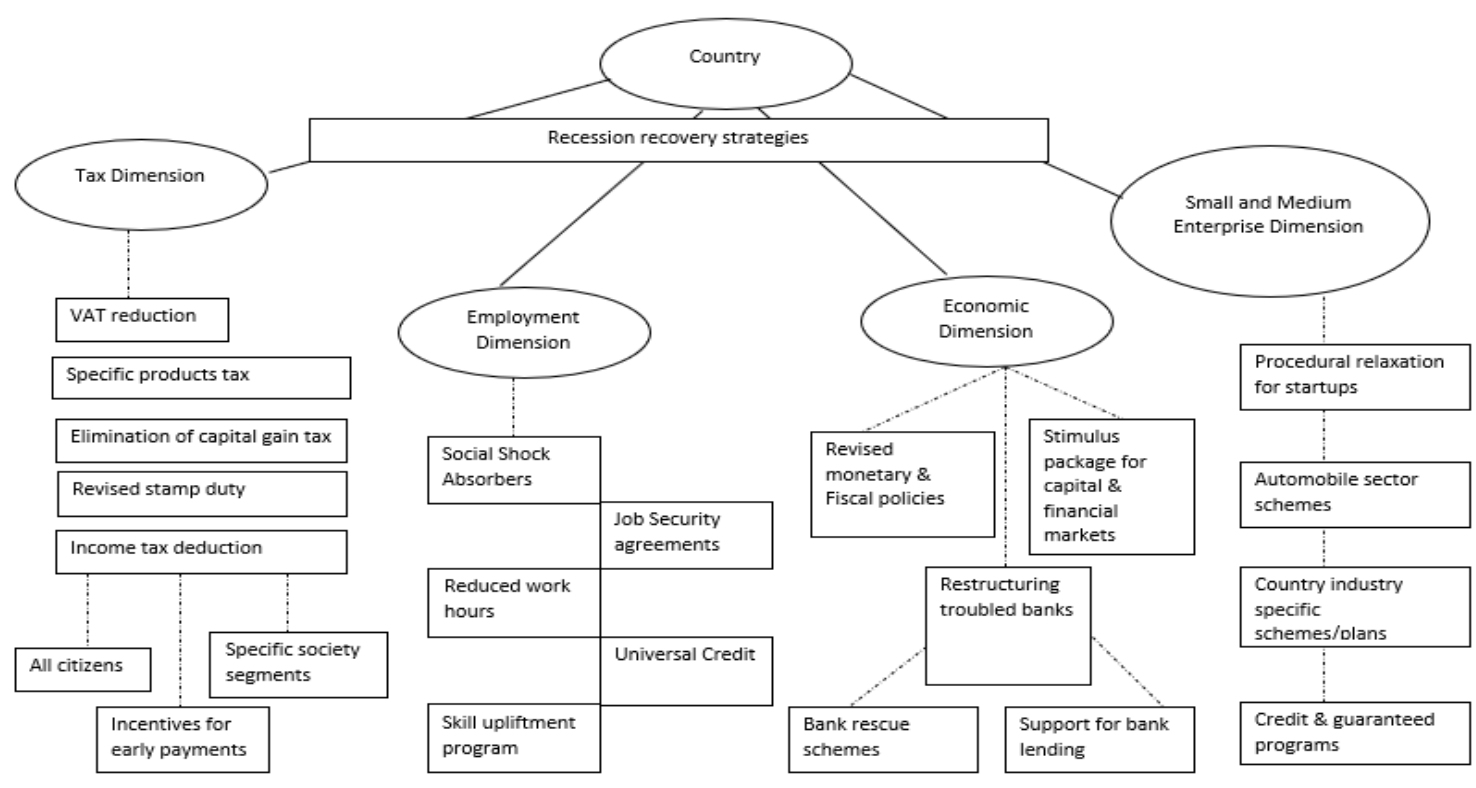

Source: Developed by authors 


\section{CONCLUSION}

Similarities between the Great Recession and the COVID-19 pandemic spell out that all countries worldwide have majorly impacted economic, financial, employment, taxation \& business areas. Various recovery strategies implemented by governments helped them to recover from the recession. Time to recover from the recession had varied depending upon the type of recovery strategies the country has implemented. In this study, the top 5 EU countries' recovery strategies were critically analyzed and observed that most countries have recovered completely or partially from the recession in a shorter span (within 5-10 years). All these countries' recovery strategies broadly fall under economic, employment, taxation \& businesses. The commonalities of the recession recovery strategies across these top 5 countries include relief/stimulus packages, lowinterest rates, increased income taxes, programs like 'cash-for-clunkers, low working hours. On the limitations side, this study has a couple of constraints, like the study is limited to only the top 5 countries of the EU region. Similarly, recommendations are based on secondary sources of data. Recession recovery strategy may be influenced by factors like region, socio-economic status, and multiple aspects of that country. Emerging countries might follow different strategies since these governments need to focus on the people's livelihood primarily. In the future, scholars can expand the study to various countries like emerging, underdeveloped countries across the globe. The study presents a generic recession recovery developmental model that policymakers can consider for formulating country-specific recovery strategies. 


\section{REFERENCES}

Aceleanu, M. (2013) The labor market in the post-crisis economy: The case of Spain. Theoretical and Applied Economics, 580 (3), 135-146

Akbar, S., Rehman, S. U., and Ormrod, P. (2013) The impact of recent financial shocks on the financing and investment policies of UK private firms. International Review of Financial Analysis. 26, 59-70.

Alshubiri, F., Jamil, S.A. and Elheddad, M. (2019) The impact of ICT on financial development: empirical evidence from the Gulf Cooperation Council countries", International Journal of Engineering Business Management, SAGE Publications STM, Vol. 11, 1847979019870670.

Blum, U, and Freye, S. (2009) Die Abwrackprämie - wer zahlt die Zeche?, IWH Pressemitteilung 29/2009. Institut für Wirtschaftsforschung Halle (IWH), Halle

Bohachova, O., Boockmann, B., and Buch, C.M. (2011) Labor Demand During the Crisis: What Happened in Germany?, IZA Discussion Paper 6074. Institute for the Study of Labor (IZA), Bonn

Bozio, A., Emmerson, C., Peichl, A., and Tetlow, G. (2015) European Public Finances and the Great Recession: France, Germany, Ireland, Italy, Spain and the United Kingdom Compared. Fiscal Studies. 36 (4), 405-430.

Brenke, K., Rinne U., and Zimmermann, K.F. (2011) Short-Time Work: The German Answer to the Great Recession, IZA Discussion Paper 5780. Institute for the Study of Labor (IZA), Bonn

Brunnermeier, M. K. (2008) Deciphering the liquidity and credit crunch 2007-08. NBER working paper no.14612. Cambridge, Mass: National Bureau of Economic Research.

Bugamelli, M., Cristadoro, R. and Zevi, G. (2009) La crisi internazionale e il sistema produttivo italiano:un'analisi su dati a livello di impresa, Occasional Papers 58, Rome: Banca d'Italia.

Bulbarelli, M. (2016) The housing finance system in Italy and Spain: Why did a housing bubble develop in Spain - and not in Italy? No 26/2016, PIPE - Papers on International Political Economy https://www.econstor.eu/bitstream/10419/149632/1/849511437.pdf [Accessed 01.02.21]

Campello, M.; Graham, J. R., and Harvey, C. R. (2010) The real effects of financial constraints: Evidence from a financial crisis. Journal of Financial Economics 97(3): 470-487.

Carballo-Cruz, F. (2011) Causes and consequences of the Spanish economic crisis: Why the recovery is taken so long?. Panoeconomicus, 58(3), 309-328.

Caliendo, M., (2009) Income Support Systems, Labor Market Policies and Labor Supply: The German Experience, IZA Discussion Paper 4665. Institute for the Study of Labor (IZA), Bonn

Calò, S., (2019) Bailouts: The lesser of two evils?," Journal of Policy Modeling, Elsevier, vol. 41(1), pages 84-98.

European Commission (2009), Economic Crisis in Europe: Causes, Consequences and Responses, European Economy 7.

Graham, J. R., Leary, T. M. and Roberts, M. R. (2014). A century of capital structure: The leveraging of corporate America. NBER working paper no. 19910. Cambridge, Mass: National Bureau of Economic Research.

Harari, D. (2014) Recession and recovery: the German experience. Wednesday, 26 February, 2014. https://commonslibrary.parliament.uk/recession-and-recovery-the-german-experience/ [Accessed 18.2.21]

Hardie, I. and Howarth, D. (2009) Die Krise and not la crise? The financial crisis and the transformation of German and French banking systems. Journal of Common Market Studies 47(5): 1017-1039.

Howarth, D. (2013) The Legacy of State-led Finance in France and the Rise of Gallic MarketBased Banking, Governance, 26(3), 369-395 
International Monetary Fund (2012) Global Financial Stability report: The quest for lasting stability. IMF, Washington, DC, April.

International Monetary Fund, (2009) What's the Damage? Medium-Term Output Dynamics after Financial Crises, World Economic Outlook, Chapter 4. Washington, DC: International Monetary Fund.

International Monetary Fund, (2009) World Economic Outlook: From Recession to Recovery: How soon and How Strong (Washington).

International Monetary Fund (2020). Fiscal Monitor: Policies to Support People during the COVID-19 Pandemic. Washington, DC, April.

Iqbal, A and Kume, O. (2014) Impact of Financial Crisis on Firms' Capital Structure in UK, France, and Germany, Multinational Finance Journal, 18(3/4), 1-38

Ivashina, V., and Scharfstein,D. (2010) Bank Lending During the Financial Crisis of 2008. Journal of Financial Economics 97(3), 319-338.

Jakbo , N. and Massoc, E. (2012) French capitalism under stress: How Nicolas Sarkozy rescued the banks, Review of International Political Economy, 19(4), 562-585

Kahle, K.M. and Stulz, R., (2013) Access to capital, investment, and the financial crisis, Journal of Financial Economics, 110, (2), 280-299

Khatiwada, S. (2009) Stimulus packages to counter global economic crisis: a review', IILS Discussion Paper, No. DP/196/2009, IILS, Geneva.

Kose, M. A. and Ohnsorge, F. (2019) A Decade After the Global Recession. Lessons and Challenges for Emerging and Developing Economies, World Bank.

Kose, M. A., Nagle, P., Ohnsorge,f., and Sugawara, N. (2020) Global Waves of Debt: Causes and Consequences. Washington, DC: World Bank.

Leifels A, Moog, S, and Raffelhüschen, B. (2009) Auswirkungen der Konjunkturpakete auf die öffentlichen Haushalte in 2009 und 2010. Kurzexpertise im Auftrag der Initiative Neue Soziale Marktwirtschaft, Freiburg

Morsy, H, and Sgherri, S., (2010) After the Crisis; Assessing the Damage in Italy, IMF Working Papers 2010/244, International Monetary Fund.

Müller, F.E. (2013) Government interventions during the Economic and Financial Crisis 2008/09: An analysis of national economic stimulus programs in response to the economic and financial crisis, No 19/2013, PIPE - Papers on International Political Eco : The housing finance system in Italy and Spain: Why did a housing bubble develop in Spain - and not in Italy?

Muñoz, L., Modroño, P., and Addabbo, T. (2014) The impact of austerity on women's work in Italy and Spain. Pablo de Olavide University.

OECD (2009) Policy Responses to the Economic Crisis: Investing in Innovation for Long-Term Growth; http://www.oecd.orgi/sti/4298341.pdf. [Accessed, 20.02.21]

Pasquino, G. (2008) The 2008 Italian national elections: Berlusconi's third victory, South European Society \& Politics, 13(3), 345-62

Quirico, R.D. (2010) Italy and the Global Economic Crisis. Bulletin of Italian Politics, 2(2), 3-19

Rahman. H.M.D., Ramón S.G., and Martínez, A.B. (2017) Economic Recession in Spain: Exploring the Root Causes, Consequences and Recoveries for the Sustainable Economic Growth. International Journal of Econometrics and Financial Management, 5(2), 60-68. DOI: 10.12691/ijefm-5-2-5

Reinhart, C. M., and Rogoff, K.S. (2009) The Aftermath of Financial Crises. American Economic Review, 99 (2): 466-72. DOI: 10.1257/aer.99.2.466

Rampell, C. (2009) Great Recession: A Brief Etymology, New York Times, March 11, 2009.

Rinne, U., and Zimmermann, K.F (2012) Another economic miracle? The German labor market and the Great Recession. IZA J Labor Policy 1, 3 (2012).

https://doi.org/10.1186/2193-9004-1-3 
Schäfer D, and Zimmermann K.F. (2009) Finanzmärkte nach dem Flächenbrand. Warum es dazu kam und was wir daraus lernen müssen, Wiesbaden

Schmidt, V. (2009) Putting the Political Back into Political Economy by Bringing the State Back in Yet Again. World Politics, 61(3), 516-46.

Schneider, S. (2014) Varieties of capitalism, varieties of crisis response Bank bailouts in comparative perspective, No 21/2014, PIPE - Papers on International Political Economy, Free University Berlin, Center for International Political Economy

Székely, I., and van den Noord. P. (2009) Economic crisis in Europe: Cause, consequences, and responses - A report by the European Commission.

https://voxeu.org/article/economic-crisis-europe-cause-consequences-and-responses [Accessed, 14.03.21]

Jasiński, T., and Mielcarz, P. (2013) Consumption as a Factor of Polish Economic Growth during the Global Recession of 2008/2009: A Comparison with Spain and Hungary. Contemporary Economics, 7(2), 5 .

Vassallo, S. (2007) Government under Berlusconi: The functioning of the core institutions in Italy, West European Politics, 30 (4), 692-710.

Verick, S., and Islam, I., (2010) The Great Recession of 2008-2009: Causes, Consequences and Policy Responses," IZA Discussion Papers 4934, Institute of Labor Economics (IZA).

Wilks, S. (2009). The Impact of the Recession on Competition Policy: Amending the Economic Constitution?, International Journal of the Economics of Business, Taylor \& Francis Journals, 16(3), 269-288

Wolf, M. (2010). The Long road ahead. The financial Times, The financial times limited, London.

Zapf, I. and Brehmer, W. (2010) Flexibilität in der Wirtschaftskrise: Arbeitszeitkonten haben sich bewährt, IAB Kurzbericht 22/ 2010. Institute for Employment Research (IAB), Nuremberg 